\title{
BIOCHEMICAL CONSTITUENTS AND BIOACTIVITY OF LAURENCIA OBTUSA (CERAMIALES, RHODOPHYTA) IN RELATION TO SEASONAL AND ECOLOGICAL FACTORS AT RED SEA COAST - EGYPT
}

\author{
Mohamed A. I. Deyab \\ Botany Department, Faculty of Science at Damietta, Mansoura University, New \\ Damietta, Egypt
}

\begin{abstract}
Physicochemical analysis of seawater at three sites along the Red Sea cost of Egypt; that is Faied, Ras Gharib and Safaga for one year revealed marked seasonal and local variation in the eutrophication status of the water, temperature and salinity. Laurancia obtusa experienced both local and temporal variation in covering percentage with a maximum dominance during summer and autumn especially at Faied. The contents of proteins, carbohydrates and lipids in L. obtusa tissues showed peaks during summer at all sites particularly at Faied. Likewise, the mineral content of the alga exhibited distinct seasonal and local variation. Chloroform extracts of $L$. obtusa were more efficient as antibacterial than as antifungal. The most sensitive bacterial species was Pseudomonas aeruginosae and the most sensitive fungal species was Fusarium spp. The L. obtusa extract harvested from Safaga was the most potent among the studied sites. The antimicrobial activity of the algal extract obtained from algae collected during autumn and winter was stronger than during summer and spring. This was in marked contrast with the levels of the primary metabolites (protein, lipids and carbohydrates) which showed maximum levels during summer.

Key Words: Antimicrobial Activities, Chemical Composition, Laurancia obtusa, Red Sea Coast- Egypt, Seaweed Flora.
\end{abstract}

\section{Introduction}

The Red Sea had been considered as one of the least polluted waters in the world (Head, 1987); yet pollution induced by anthropogenic activities including oil spills and excessive loading of nutrients, particularly phosphate, through the addition of fertilizers, and discharge of industrial wastewater and sewage have been reported during the last decade (Abou-Aisha et al., 1995). The physicochemical characteristics of water determined primarily by the locality and the season considerably influence the distribution, growth and chemical composition of algal species (Kuwana et al., 1998). The algal content of carbohydrates, proteins, lipids, free amino acids and minerals vary according to species, geographical location, season and temperature (Shanmugam and Palpandi, 2008). Algae have the ability to produce primary as well as secondary 
metabolites which might be of potential value as bioactive ingredients in the pharmacological industry (Attaway and Zaborsky, 1993). Laurencia obtusa are rich source of polyhalogenated sesquiterpenes with different types of skeleton among other different natural products such as hurgadenyne, $\beta$-snyderyl acetate, hurgadol, n-heptadecane, obtusane, 3- $\beta$-bromo- 8 -epicaparrapi oxide, (E)-2tridecyl-2-heptadecenal, $\beta$-synderol, palmitic acid and cholesterol (Martin and Darias, 1978; Erickson, 1983; Martin et al., 1989). Special attention has been reported for antiviral, antibacterial and/or antifungal activities related to marine algae against several pathogens. As an efficient strategy of investigation, organic solvents have been used to extract the possible soluble active principles from macroalgae (Lima-Filho et al., 2002; Demirel et al., 2011).

The present work aims to investigate the seasonal variation in the chemical composition of L. obtusa at different sites along the Red Sea coast of Egypt. The antimicrobial activity of L. obtusa extracts against some pathogenic bacteria and fungi will be investigated in relation to the environmental conditions.

\section{Materials and Methods}

Three sites representing the shores of the Suez Canal, Suez Gulf and Red Sea Coast; that is Faied, Ras Gharib and Safaga respectively were seasonally investigated (Figure 1). For physicochemical analysis surface water samples were collected two times a season for one year from May 2008 to May 2009. Chemical analysis of water samples was performed according to Strikland and Parsons (1972). Percentage covering of $L$. obtusa was determined using a $1 \mathrm{~m} 2$ quadrate at low tide. Algal biomass was cleaned from impurities and thoroughly washed with distilled water, blotted gently and fresh weight was recorded. Air-dried samples were re-weighed for dry weight estimation, then ground and stored at room temperature $\left(20-30^{\circ} \mathrm{C}\right)$ for analysis.

Protein content of the alga was determined spectrophotometrically according to the method of Bradford (1976) using coomassie brilliant blue G-250 using a double beam recording spectrophotometer at $595 \mathrm{~nm}$. Total carbohydrates were determined spectrophotometrically using the anthrone method adopted by Schortemeyer et al. (1997). Total lipids were extracted in a soxhlet system using petroleum ether (40-60) according to the procedure of AOCS (1993). The algal dry mass was digested according to the Microkhjeldahl method of Hawk $\boldsymbol{e t}$ al. (1947). The contents of potassium, sodium and calcium in the clear digest were determined using Flame Photometer (Jenway PFP7) and total phosphorus was determined according to the method of John (1970). Heavy metals in the dried algal samples were extracted by digestion according to Moore and Chapman (1986). Algal extracts were diluted up to 100 times before injection into a Perkin Elmer 2380 Atomic Absorption Spectrophotometer. For estimation of antimicrobial activity, algal biomass was extracted with chloroform using soxhlet 
apparatus, and the residue was evaporated and re-dissolved in dimethyl sulfoxide (DMSO).

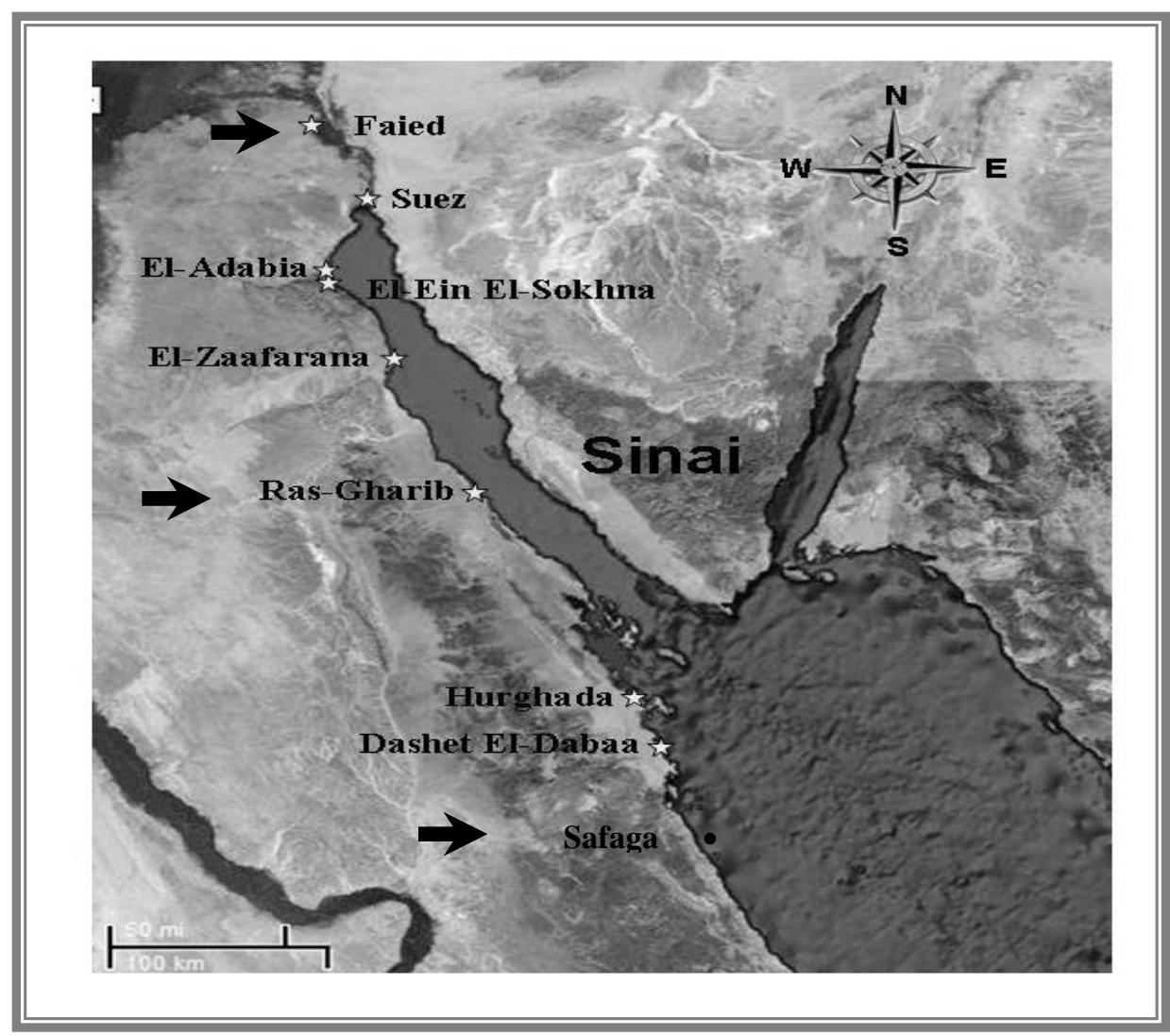

Figure (1): The study area at Suez Canal (Faied), Suez Gulf (Ras Gharib) and Red Sea (Safaga).

Algal extracts were tested for antibacterial and antifungal activity according to the method of Calvo et al. (1986). Using a sterile cork borer, $10 \mathrm{~mm}$ wells were cut off from agar and $0.3 \mathrm{ml}$ of L. obtusa extract was introduced into each well. For the control, $0.3 \mathrm{ml}$ of DMSO was used. The tested bacterial species were Staphylococcus aureus, Bacillus cereus, Micrococcus roseus, Escherichia coli, Pseudomonas aeruginosae, Klebsiella pneumoniae and Enterobacter cloacae and the tested fungi were Alternaria alternata, Aspergillus niger, A. flavus, Fusarium oxysporium-pisi, F. solani, Botrytis fabae and Rhizocotonia solani. Inhibition zones were measured in millimeters after one day incubation at $37^{\circ} \mathrm{C}$ for bacteria and after $5-6$ days at $28^{\circ} \mathrm{C}$ for fungi. Each assay was repeated twice 
and the mean values were recorded. Pearson's correlation coefficient (r) was calculated using SPSS. Inc., 1999 program (version 10).

\section{Results}

The physicochemical characteristics of the sea water at the three sites of study over one year period were presented in Table (1). Water temperature exhibited marked seasonal and local variation, with a minimum of $18^{\circ} \mathrm{C}$ at Faied in winter and a maximum of $34^{\circ} \mathrm{C}$ at Safaga in summer. Water was slightly alkaline in average and the $\mathrm{pH}$ ranged from 7.6 to 8.2 (Table 1). The levels of salinity (estimated as g dissolved slats per liter), chloride, total hardness, electric conductivity and dissolved oxygen of water were relatively lower than average during winter especially at Faied but higher during summer especially at Safaga. Total alkalinity was lowest $\left(2.4 \mathrm{meq}^{-1}\right)$ at Safaga during autumn and highest (3.4 meq $1^{-1}$ ) during spring at Faied.

Table (1): Physicochemical analysis of water at the three sites of study areas over one year period. Each value is the mean of three replicates $\pm \mathrm{SE}$.

\begin{tabular}{|c|c|c|c|c|c|c|c|c|c|c|c|c|}
\hline \multirow{3}{*}{ Characteristic } & \multicolumn{12}{|c|}{ Stations } \\
\hline & \multicolumn{4}{|c|}{ Faiel } & \multicolumn{4}{|c|}{ RasGlarib } & \multicolumn{4}{|c|}{ Safag } \\
\hline & Spring & Summer & Antumn & Winter & Spring & Summer & Autumn & Winter & Spring & Summer & Autumn & Winter \\
\hline Temperature $\left({ }^{\circ} \mathrm{C}\right)$ & $24 \pm 0.5$ & $28 \pm 1.2$ & $25 \pm 1.3$ & $18 \pm 1.1$ & $25 \pm 1.3$ & $31 \pm 2.3$ & $28 \pm 1.2$ & $25 \pm 1.2$ & $27 \pm 1.4$ & $34 \pm 2.5$ & $29 \pm 2.1$ & $28 \pm 2.2$ \\
\hline $\mathrm{pH}$ & $7.9 \pm 0.1$ & $8.1 \pm 0.07$ & $8.1 \pm 0.8$ & $785 \pm 1$ & $7,9 \pm 0.5$ & $7.6 \pm 0.6$ & $7.9 \pm 0.7$ & $79 \pm 0.8$ & $8 \pm 0.9$ & $7.6 \pm 1$ & $8.2 \pm 0.1$ & $7.8 \pm 0.2$ \\
\hline $\mathrm{EC}^{\prime}$ (mmohs cm- $\left.{ }^{-1}\right)$ & $41.9 \pm 1$ & $46 \pm 23$ & $48 \pm 1.5$ & $44.1 \pm 2.1$ & $56.4 \pm 2.6$ & $62.4 \pm 2.3$ & $50 \pm 2$ & $54.8 \pm 2.6$ & $60.2 \pm 2.1$ & $64.2 \pm 2.2$ & $61.6 \pm 2.5$ & $54.2 \pm 23$ \\
\hline Salinity $\left(g I^{1}\right)$ & $379 \pm 0.8$ & $38.8 \pm 2.1$ & $38.8 \pm 1.1$ & $37.5 \pm 1.6$ & $39.6 \pm 1.5$ & $40.1 \pm 18$ & $40 \pm 13$ & $39.4 \pm 2.1$ & $40.2 \pm 1.4$ & $40.8 \pm 1.5$ & $40.4 \pm 1.8$ & $40.1 \pm 19$ \\
\hline Total Alkal. (meq I ${ }^{1}$ ) & $3.4 \pm 0.01$ & $29 \pm 0.1$ & $2.9 \pm 0.2$ & $3.1 \pm 0.3$ & $2.9 \pm 0.1$ & $2.9 \pm 0.5$ & $2.6 \pm 0.3$ & $25 \pm 0.2$ & $3.1 \pm 0.1$ & $2.7 \pm 0.2$ & $2.6 \pm 05$ & $2.7 \pm 0.4$ \\
\hline $\mathrm{DO}\left(\mathrm{mgl}^{\mathrm{l}}\right)$ & $8.6 \pm 0.2$ & $88 \pm 05$ & $9.2 \pm 0.6$ & $8.6 \pm 0.1$ & $11.3 \pm 0.3$ & $129 \pm 09$ & $10 \pm 0.8$ & $93 \pm 09$ & 13.1 $1 \pm 09$ & $14.2 \pm 0.9$ & $13.8 \pm 1.1$ & $113 \pm 1$ \\
\hline $\mathrm{BOD}\left(\mathrm{mg} \mathrm{I}^{\mathrm{l}}\right)$ & $2.3 \pm 0.02$ & $3.1 \pm 0.05$ & $2.0 \pm 0.05$ & $2.4 \pm 0.03$ & $2.1 \pm 0.6$ & $1.0 \pm 0.06$ & $1.6 \pm 0.05$ & $1.4 \pm 0.02$ & $1.0 \pm 0.02$ & $1.5 \pm 0.01$ & $1.4 \pm 0.05$ & $1.5 \pm 0.01$ \\
\hline Ammonia-N $\left(\mathrm{mgl}^{\mathrm{l}}\right)$ & $0.09 \pm 0$ & $0.06 \pm 0$ & $0.08 \pm 0$ & $0.06 \pm 0$ & $0.07 \pm 0$ & $0.05 \pm 0$ & $0.07 \pm 0$ & $0.04 \pm 0$ & $0.06 \pm 0$ & $0.06 \pm 0$ & $0.03 \pm 0$ & $0.03 \pm 0$ \\
\hline Nitrite $N\left(\mathrm{mgl}_{\mathrm{g}} \mathrm{l}^{\mathrm{l}}\right)$ & $0.04 \pm 0$ & $0.03 \pm 0$ & $0.03 \pm 0$ & $0.03 \pm 0$ & $0.01 \pm 0$ & $0.01 \pm 0$ & $0.02 \pm 0$ & $0.03 \pm 0$ & $0.02 \pm 0$ & $0.02 \pm 0$ & $0.02 \pm 0$ & $0.02 \pm 0$ \\
\hline Nitrate $N\left(\mathrm{mgl}^{\mathrm{l}}\right)$ & $0.08 \pm 0$ & $0.03 \pm 0$ & $0.02 \pm 0$ & $0.04 \pm 0$ & $0.05 \pm 0$ & $0.02 \pm 0$ & $0.02 \pm 0$ & $0.01 \pm 0$ & $0.03 \pm 0$ & $0.04 \pm 0$ & $0.02 \pm 0$ & $0.03 \pm 0$ \\
\hline Total-P $\left(\mathrm{mgl}^{\mathrm{l}}\right)$ & $4.11 \pm 0.05$ & $3.14 \pm 0.3$ & $3.04 \pm 0.04$ & $2.04 \pm 0.03$ & $1.6 \pm 0.02$ & $0.9 \pm 0.01$ & $0.76 \pm 0.02$ & $0.7 \pm 0.01$ & $11.2 \pm 0.05$ & $8.6 \pm 0.06$ & $8.04 \pm 0.01$ & $7.64 \pm 0.7$ \\
\hline Silia (mgl $\left.{ }^{\mathbf{l}}\right)$ & $2.5 \pm 0.04$ & $3.6 \pm 0.1$ & $1.9 \pm 0.05$ & $2.4 \pm 0.1$ & $1.4 \pm 0.03$ & $2.7 \pm 0.06$ & $1.5 \pm 0.03$ & $0.95 \pm 0.02$ & $2.01 \pm 0.2$ & $1.8 \pm 0.1$ & $0.9 \pm 0.01$ & $1.8 \pm 0.02$ \\
\hline Chlonides $\left(m g I^{1}\right)$ & $208 \pm 1.2$ & $21.8 \pm 1.5$ & $218 \pm 1.1$ & $20.8 \pm 1.3$ & $21.8 \pm 1.8$ & $22 \pm 1.1$ & $21.8 \pm 1.3$ & $21.4 \pm 1.2$ & $22.4 \pm 1.3$ & $32.7 \pm 1.2$ & $32.3 \pm 1.1$ & $22.8 \pm 13$ \\
\hline Total-Hard. & $5.5 \pm 0.6$ & $7.1 \pm 08$ & 7.1 10.9 & $4.1 \pm 0.7$ & $7.6 \pm 0.8$ & $6.2 \pm 1$ & $6.5 \pm 0.9$ & $6.4 \pm 0.8$ & $8.3 \pm 0.9$ & $12.2 \pm 1.1$ & $8.4 \pm 0.8$ & $9.1 \pm 0.9$ \\
\hline
\end{tabular}

Egyptian J. of Phycol. Vol. 12, 2011

- 36 - 
The maximum value of BOD (3.9 $\left.\mathrm{mg} \mathrm{l}^{-1}\right)$ was recorded at Faied during winter, while the minimum $\left(1.5 \mathrm{mg} \mathrm{l}^{-1}\right)$ was recorded at Safaga with minor seasonal variation. The highest values of nitrate, nitrite and ammonia $\left(0.08 \mathrm{mg} \mathrm{l}^{-1}\right.$, $0.04 \mathrm{mg} \mathrm{l}^{-1}$ and $0.09 \mathrm{mg} \mathrm{l}^{-1}$ respectively) were recorded at Faied during spring. Total phosphorus exhibited considerable seasonal and local variations (Table 1); with high levels (11.2 $\mathrm{mg} \mathrm{l}^{-1}$ ) at Safaga during spring and low levels at Ras Gharib during autumn and winter. The highest level of silica $\left(3.6 \mathrm{mg} \mathrm{l}^{-1}\right)$ was recorded at Faied during summer and the lowest value $\left(0.9 \mathrm{mg} \mathrm{l}^{-1}\right)$ at Safaga during autumn (Table 1).

Figure (2) shows that the covering percentage of L. obtusa varied according to season and site with maximum and minimum abundances at Faied during autumn and winter respectively. The seasonal variation in L. obtuse dominance was thus particularly evident at Faied compared to the other sites of study; where the covering percentage was raised from $10 \%$ in spring to a maximum of $40 \%$ during autumn and then dropped to a minimum of $7 \%$ in winter, ( i.e. a fivefold change). By contrast, the seasonal variation at Safaga was only 1.5 fold. Moreover, while minimum abundance was generally recorded in winter, the timing of maximum abundance varied according to the site; with Faied and Safaga showing peaks in autumn and Ras Gharib in summer.

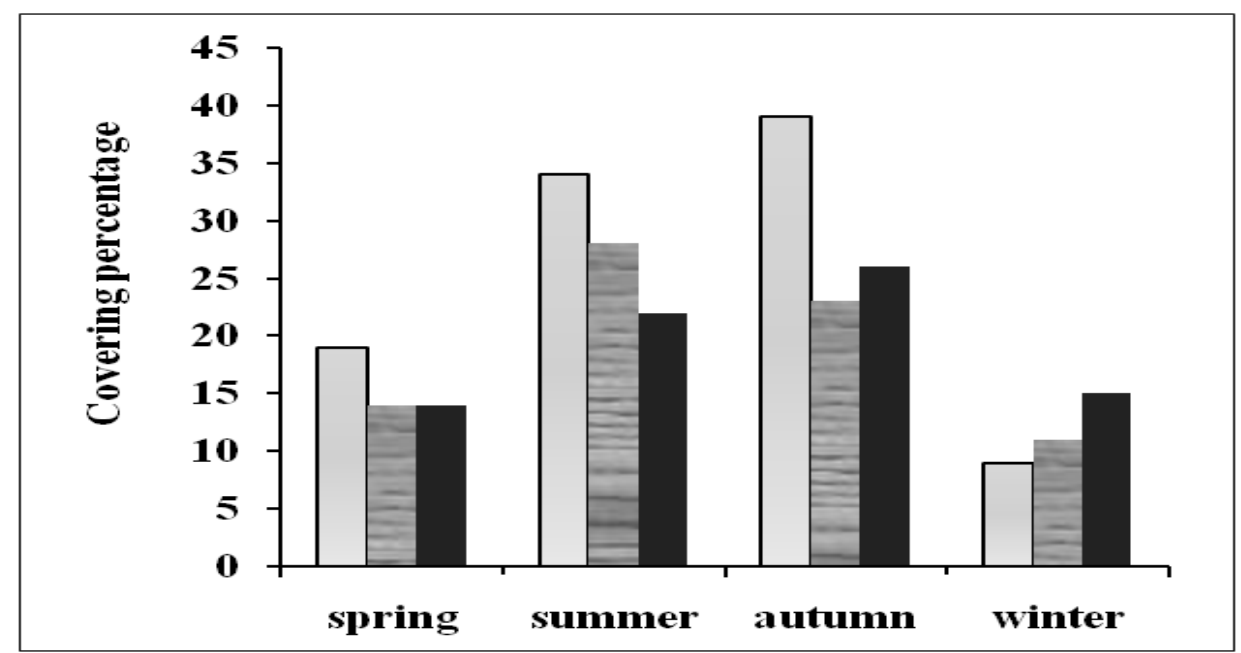

Figure (2): Seasonal variation in the covering percentage of Laurencia obtusa during the studied period

Biochemical analysis revealed that the contents of proteins, lipids and carbohydrates in L. obtuse tissues showed peaks during summer. However, the minimum levels of lipids were recorded during spring and those of proteins and carbohydrates during winter (Table 2). Among the three sites of study the contents of proteins, lipids and carbohydrates were highest at Faied and least at Safaga and 
Ras Gharib. The highest seasonal variability in protein content (four fold) was detected at Safaga that in soluble carbohydrate content (40 fold) at Faied, while that in lipid content (five fold) was at both Safaga and Faied. The content of insoluble carbohydrate content exhibited relatively small seasonal variability (less than two fold at the different sites).

Table (2): Biochemical analysis of Laurencia obtusa at different sites of the studied area in four seasons. Each value is the mean of three replicates $\pm \mathrm{SE}$.

\begin{tabular}{|c|c|c|c|c|c|c|c|c|c|c|c|c|}
\hline \multirow{3}{*}{$\begin{array}{l}\text { Biochemical } \\
\text { Analysis } \\
\text { (mg g-l diy wt) }\end{array}$} & \multicolumn{12}{|c|}{ Sites } \\
\hline & \multicolumn{4}{|c|}{ Fajed } & \multicolumn{4}{|c|}{ RasG'harib } & \multicolumn{4}{|c|}{ Safagn } \\
\hline & Spring & Sunmer & Altumn & Winter & Spring & Summer & Altumn & Winter & Spring & Summer & Autumn & Winter \\
\hline Proteill & $22.3 \pm 0.4$ & $39.6 \pm 0.2$ & $19.8 \pm 0.4$ & $18.8 \pm 2.0$ & $21.9 \pm 2.8$ & $33.1 \pm 1.6$ & $198 \pm 08$ & $14.0 \pm 1.2$ & $22.2 \pm 1.2$ & 32. $0 \pm 0.9$ & $21.4 \pm 1.2$ & $7.8 \pm 1.0$ \\
\hline Sol C'arbohydrates & $8.7 \pm 0.2$ & $59.5 \pm 0.2$ & $7.2 \pm 0.3$ & $1.5 \pm 0.3$ & $2.4 \pm 0.1$ & $9.7 \pm 0.2$ & $6.9 \pm 0.2$ & $5.2 \pm 0.2$ & $11.0 \pm 0.1$ & $50.7 \pm 0.3$ & $5.8 \pm 0.1$ & $11.2 \pm 0.3$ \\
\hline Ins. C'arbohydrates & $165.5 \pm 0.2$ & $223,6 \pm 0.3$ & $179.2 \pm 0.2$ & $1418 \pm 0.4$ & $1083 \pm 33$ & $171.4 \pm 0.02$ & $112.6 \pm 0.3$ & $95.0 \pm 0.04$ & $130.8 \pm 0.3$ & $17.6 \pm 0.2$ & $102.8 \pm 0.2$ & $113.1 \pm 0.2$ \\
\hline Lipid & $2.7 \pm 0.3$ & $13,7 \pm 0.7$ & $8.3 \pm 1.7$ & $7,9+1.0$ & $4.3+5.7$ & $9.2 \pm 0.8$ & $8.5 \pm 0.1$ & $8.0 \pm 1.0$ & $2.3 \pm 0.3$ & $11,7 \pm 0.9$ & $8.7 \pm 1.7$ & $7.7 \pm 1.3$ \\
\hline Total K & $17.2 \pm 1.0$ & $28.6 \pm 09$ & $273 \pm 15$ & $15.3 \pm 1.0$ & $10.7 \pm 0.8$ & $10.4 \pm 1.1$ & $22.8 \pm 08$ & $17.7 \pm 1.2$ & $9.4 \pm 0.4$ & $10.4 \pm 1.4$ & $14.0 \pm 0.9$ & $36.1 \pm 1.1$ \\
\hline Total Na & $168 \pm 2.4$ & $255 \pm 0.8$ & $25.4 \pm 19$ & $20.0 \pm 0.5$ & $16.8 \pm 1.9$ & $20.5 \pm 0.6$ & $246 \pm 0.4$ & $30.0 \pm 1.6$ & $24.0 \pm 2.5$ & $15.4 \pm 1.6$ & $12.2 \pm 0.3$ & $38.5 \pm 0.5$ \\
\hline Total Ca & $160 \pm 09$ & $32.8 \pm 0.7$ & $20.4 \pm 13$ & $23.4 \pm 0.9$ & $24.5 \pm 2.0$ & $18.6 \pm 03$ & $373 \pm 09$ & $34.6 \pm 0.2$ & $31.1 \pm 1.2$ & $31,1 \pm 0.9$ & $32.7 \pm 2.1$ & $34.8 \pm 0.3$ \\
\hline TotalP & $7.9 \pm 0.4$ & $66.7 \pm 0.5$ & $10.8 \pm 16$ & $4.8 \pm 0.4$ & $7.9 \pm 1.2$ & $7,0 \pm 0.4$ & $256 \pm 0.2$ & $11.0 \pm 0.5$ & $10.3 \pm 1.6$ & $0.4 \pm 0.3$ & $73.5 \pm 3.0$ & $78.4 \pm 0.9$ \\
\hline Total Fe & $0.4 \pm 0.01$ & $0.4 \pm 0.0$ & $0.3 \pm 0.01$ & $0.4 \pm 0.0$ & $0.4 \pm 0.03$ & $0.4 \pm 0.0$ & $0.4 \pm 0.0$ & $0.4 \pm 0.0$ & $0.4 \pm 0.02$ & $0.4 \pm 0.3$ & $0.3 \pm 0.03$ & $0.4 \pm 0.0$ \\
\hline Total Co & $0.8 \pm 0.03$ & $0.9 \pm 0.01$ & $0.7 \pm 0.04$ & $0.9 \pm 0.0$ & $0.8 \pm 0.1$ & $0.0 \pm 0.01$ & $0.7 \pm 0.01$ & $09 \pm 0.0$ & $09 \pm 0.03$ & $0.8 \pm 0.02$ & $0.8 \pm 0.1$ & $09 \pm 0.01$ \\
\hline Total Mn & $0.7 \pm 0.02$ & $0.7 \pm 0.01$ & $0.0 \pm 0.03$ & $0.7 \pm 0.0$ & $0.6 \pm 0.1$ & $0.7 \pm 0.01$ & $0.7 \pm 0.01$ & $0.8 \pm 0.0$ & $0.7 \pm 0.03$ & $0.7 \pm 0.02$ & $0.6 \pm 0.1$ & $0.7 \pm 0.01$ \\
\hline Total Cd & $1.1 \pm 0.03$ & $1.2 \pm 0.01$ & $0.9 \pm 0.04$ & $1.1 \pm 0.01$ & $1.0 \pm 0.1$ & $1.2 \pm 0.02$ & $1.2 \pm 0.02$ & $1.2 \pm 0.01$ & $1.2 \pm 0.04$ & $1.1 \pm 0.04$ & $0.9 \pm 0.1$ & $1.1 \pm 0.01$ \\
\hline Total Cu & $0.4 \pm 0.01$ & $0.5 \pm 0.01$ & $0.4 \pm 0.02$ & $0.4 \pm 0.0$ & $0.4 \pm 0.03$ & $0.5 \pm 0.0$ & $0.5 \pm 0.0$ & $0.5 \pm 0.0$ & $0.5 \pm 0.02$ & $0.4 \pm 0.01$ & $0.4 \pm 0.04$ & $0.5 \pm 0.0$ \\
\hline Total Zn & $0.8 \pm 0.02$ & $0.8 \pm 0.01$ & $0.0 \pm 0.03$ & $0.8 \pm 0.0$ & $0.7 \pm 0.1$ & $0.8 \pm 0.01$ & $0.7 \pm 0.02$ & $0.8 \pm 0.0$ & $0.8 \pm 0.03$ & $0.7 \pm 0.02$ & $0.7 \pm 0.1$ & $0.8 \pm 0.01$ \\
\hline
\end{tabular}

The mineral content of the alga exhibited considerable variation according to site and season. The contents of $\mathrm{K}, \mathrm{Na}$ and $\mathrm{P}$ in L. obtusa tissues were highest at Safaga during winter, those of $\mathrm{Ca}$ at Ras Gharib during autumn. The lowest levels of $\mathrm{K}$ were found at Safaga during summer, those of $\mathrm{Na}$ at Safaga during autumn, those of $\mathrm{Ca}$ at Faied during summer and those of $\mathrm{P}$ at Faied during winter. Certain sites exhibited highest average levels of certain minerals. In general, the highest average content of $\mathrm{K}$ was found at Faied, where those of $\mathrm{Ca}$ 
and $\mathrm{P}$ are at Safaga. By contrast, the lowest average contents of $\mathrm{K}$ and $\mathrm{P}$ were found at Ras Gharib while the lowest content of $\mathrm{Ca}$ was found at Faied. The content of $\mathrm{Na}$ was comparable at the three sites with relatively small local and seasonal variations and averaged about $22.5 \mathrm{mg} \mathrm{g}^{-1} \mathrm{DW}$. The contents of minerals in L. obtuse tissues were subjected to seasonal variation and the magnitude of this variation differed according to site. The contents of $\mathrm{K}$ and $\mathrm{Na}$ exhibited the greatest seasonal variability (four and three fold respectively) at Safaga and the least seasonal variability (less than two fold) at Faied. The greatest variability in $\mathrm{Ca}$ and $\mathrm{P}$ contents (two and fourteen fold respectively) were found at Faied, while the least variability in $\mathrm{Ca}$ content (almost constant seasonal level) was found at Safaga and in P content ( only three fold change) was found at Ras Gharib. The contents of heavy metals in the algal tissues were subjected to minor seasonal and local variability, with an average of $0.38,0.83,0.68,1.1,0.45$ and $0.75 \mathrm{mg} \mathrm{g}^{-1}$ DW for $\mathrm{Fe}, \mathrm{Co}, \mathrm{Mn}, \mathrm{Cd}, \mathrm{Cu}$ and $\mathrm{Zn}$ respectively over all sites and all seasons.

The antimicrobial activity of $L$. obtusa extracts was investigated against seven bacterial and seven fungal species Table (3).

Table (3): Antimicrobial activity of Laurencia obtuse extract at different sites of the studied area in four seasons. Each value is the mean of three replicates $\pm \mathrm{SE}$.

\begin{tabular}{|c|c|c|c|c|c|c|c|c|c|c|c|c|}
\hline \multirow{3}{*}{ Microbial species } & \multicolumn{12}{|c|}{ Stations } \\
\hline & \multicolumn{4}{|c|}{ Faied } & \multicolumn{5}{|c|}{ Ras Gharib } & \multicolumn{3}{|c|}{ Safaga } \\
\hline & spring & summer & autumn & winter & spring & summer & autumn & winter & spring & summer & autumn & winter \\
\hline Staplyylococcus antrens & $1.2 \pm 0.02$ & $2 \pm 0.02$ & $5 \pm 0.05$ & $3 \pm 0.03$ & $1 \pm 0.01$ & $1.8 \pm 0.02$ & $2 \pm 0.02$ & $3 \pm 0.03$ & $5 \pm 0.05$ & $4.5 \pm 0.05$ & $5 \pm 0.05$ & $4 \pm 0.04$ \\
\hline Bacilliss cerens & $1 \pm 0.01$ & $2.1 \pm 0.02$ & $3.5 \pm 0.04$ & $3 \pm 0.03$ & $1 \pm 0.01$ & $1 \pm 0.01$ & $2 \pm 0.02$ & $3 \pm 0.03$ & $2 \pm 0.02$ & $4 \pm 0.04$ & $4 \pm 0.05$ & $3 \pm 0.03$ \\
\hline Escherichia coli & $1 \pm 0.01$ & $1.4 \pm 0.02$ & $2.4 \pm 0.04$ & $2 \pm 0.02$ & $2 \pm 0.02$ & $2 \pm 0.02$ & $2.5 \pm 0.02$ & $2 \pm 0.02$ & $1.1 \pm 0.01$ & $1.5 \pm 0.01$ & $2.3 \pm 0.02$ & $2 \pm 0.02$ \\
\hline Pserudomonas aernginosu & $5 \pm 0.05$ & $4 \pm 0.04$ & $10 \pm 0.1$ & $9 \pm 0.09$ & $3 \pm 0.02$ & $3 \pm 0.03$ & $6 \pm 0.2$ & $5 \pm 0.04$ & $2.5 \pm 0.02$ & $9 \pm 0.2$ & $15 \pm 0.3$ & $11 \pm 0.1$ \\
\hline Micrococcus rosens & $1.1 \pm 0.01$ & $1.2 \pm 0.02$ & $2 \pm 0.03$ & $3 \pm 0.03$ & $1 \pm 0.01$ & $1.4 \pm 0.01$ & $1.8 \pm 0.02$ & $3 \pm 0.03$ & $1.1 \pm 0.01$ & $3 \pm 0.03$ & $5 \pm 0.05$ & $6 \pm 0.05$ \\
\hline Enterobacter cloacae & $1.1 \pm 0.01$ & $1.4 \pm 0.02$ & $1.6 \pm 0.02$ & $2.6 \pm 0.04$ & $1.1 \pm 0.01$ & $1.2 \pm 0.01$ & $1.4 \pm 0.01$ & $3.1 \pm 0.03$ & $1.1 \pm 0.01$ & $3 \pm 0.03$ & $4 \pm 0.04$ & $5 \pm 0.03$ \\
\hline Klebsiella prenuneniae & $1.1 \pm 0.01$ & $1.2 \pm 0.02$ & $2.1 \pm 0.02$ & $3.1 \pm 0.03$ & $1 \pm 0.01$ & $2 \pm 0.02$ & $2.5 \pm 0.03$ & $3.2 \pm 0.03$ & $1.1 \pm 0.01$ & $2.5 \pm 0.03$ & $2.8 \pm 0.02$ & $4 \pm 0.04$ \\
\hline Aspergillus niger & $1.5 \pm 0.03$ & $3 \pm 0.02$ & $4 \pm 0.04$ & $5 \pm 0.05$ & $1 \pm 0.01$ & $2 \pm 0.02$ & $3 \pm 0.02$ & $4 \pm 0.04$ & $1.1 \pm 0.01$ & $3 \pm 0.03$ & $4 \pm 0.04$ & $5 \pm 0.05$ \\
\hline Aspergillius flavis & $2 \pm 0.02$ & $2 \pm 0.02$ & $2 \pm 0.02$ & $4 \pm 0.04$ & $1 \pm 0.01$ & $1 \pm 0.01$ & $1 \pm 0.01$ & $3 \pm 0.03$ & $1.3 \pm 0.01$ & $2 \pm 0.02$ & $2 \pm 0.02$ & $4 \pm 0.05$ \\
\hline Fussurium solani & $3 \pm 0.02$ & $3.2 \pm 0.02$ & $6 \pm 0.06$ & $7 \pm 0.06$ & $3 \pm 0.02$ & $3.2 \pm 0.03$ & $5 \pm 0.05$ & $4 \pm 0.04$ & $3 \pm 0.03$ & $4.2 \pm 0.04$ & $6 \pm 0.05$ & $8 \pm 0.06$ \\
\hline Fussurium oxysportm-pisi & $3.2 \pm 0.03$ & $3.5 \pm 0.03$ & $4 \pm 0.04$ & $5 \pm 0.05$ & $2.1 \pm 0.02$ & $2.2 \pm 0.02$ & $3.2 \pm 0.03$ & $3 \pm 0.03$ & $2.8 \pm 0.02$ & $3.4 \pm 0.03$ & $4 \pm 0.04$ & $6.2 \pm 0.05$ \\
\hline Botrytis fabue & $1 \pm 0.01$ & $1.2 \pm 0.01$ & $1.5 \pm 0.02$ & $2 \pm 0.02$ & $1.1 \pm 0.01$ & $1.4 \pm 0.01$ & $1.6 \pm 0.02$ & $3 \pm 0.03$ & $1.1 \pm 0.01$ & $1.3 \pm 0.01$ & $2 \pm 0.02$ & $4 \pm 0.04$ \\
\hline Alternurin alternuta & $1.1 \pm 0.01$ & $1.3 \pm 0.02$ & $2 \pm 0.02$ & $2.5 \pm 0.02$ & $1 \pm 0.01$ & $1.2 \pm 0.01$ & $1.5 \pm 0.01$ & $3 \pm 0.03$ & $1.3 \pm 0.01$ & $2 \pm 0.02$ & $2.1 \pm 0.02$ & $4.2 \pm 0.04$ \\
\hline Rlizocotoniu soluni & $1 \pm 0.01$ & $1.1 \pm 0.01$ & $1.4 \pm 0.02$ & $2.3 \pm 0.02$ & $1 \pm 0.01$ & $1.3 \pm 0.01$ & $1.8 \pm 0.02$ & $3 \pm 0.03$ & $1 \pm 0.01$ & $1.2 \pm 0.01$ & $2 \pm 0.02$ & $2.2 \pm 0.02$ \\
\hline
\end{tabular}


The data revealed that, in general, the antibacterial activity of the algal extract was more potent than the antifungal activity. The most affected bacterial species was Pseudomonas aeruginosa and the most affected fungal species was Fusarium solani. The least affected bacterial species were Escherichia coli and Enterobacter cloacae and the least affected fungal species were Botrytis fabae and Rhizocotonia solani. The antimicrobial activity of the algal extracts obtained at Safaga was the highest, followed by those obtained at Faied. By contrast, the maximum antibacterial activity against $E$. coli and the antifungal activity against $R$. solani were at Ras Gharib. Furthermore, the data revealed that during winter and autumn the antimicrobial activity were highest than during summer and spring. Also the data shows that the antibacterial activity of L. obtusa was positively correlated with the water $\mathrm{pH}$, alkalinity, phosphorus and chloride contents but negatively correlated with temperature, ammonia and silica. The antifungal activity showed positive correlation with $\mathrm{pH}$ and chloride but negative correlation with alkalinity; nitrite, ammonia and nitrate (Table 4).

Table (4): Correlation coefficient between mean antibacterial and mean antifungal activities of the investigated Laurencia obtuse and the mean environmental condition.

\begin{tabular}{|c|c|c|c|c|c|c|c|c|c|c|c|c|c|c|}
\hline \multirow[b]{3}{*}{$\begin{array}{l}\text { Environmental } \\
\text { Condition }\end{array}$} & \multicolumn{14}{|c|}{ Tested species } \\
\hline & \multicolumn{7}{|c|}{ Antibacterial } & \multicolumn{7}{|c|}{ Antifumgal } \\
\hline & s & $\begin{array}{l}5 \\
5 \\
5 \\
5 \\
0\end{array}$ & 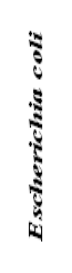 & $\begin{array}{l}5 \\
8 \\
8 \\
8\end{array}$ & $\begin{array}{l}8 \\
8 \\
8 \\
8 \\
8 \\
8 \\
8 \\
8\end{array}$ & $\begin{array}{l}8 \\
8 \\
8 \\
8 \\
8 \\
8 \\
8\end{array}$ & 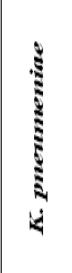 & 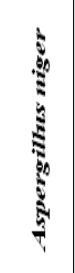 & s & $\begin{array}{l}5 \\
5 \\
5 \\
5 \\
5 \\
5\end{array}$ & 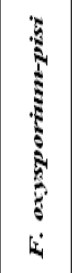 & $\begin{array}{l}0 \\
8 \\
8\end{array}$ & $\begin{array}{l}\$ \\
5 \\
5 \\
5 \\
5 \\
5\end{array}$ & 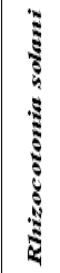 \\
\hline Temperature & -0.152 & -0.023 & -0.313 & -0.125 & -0.185 & -0.338 & -0.037 & -0.137 & -0.210 & 0.120 & -0.159 & -0.081 & -0.068 & -0.147 \\
\hline $\mathrm{pH}$ & -0.141 & 0.115 & 0.170 & 0.206 & -0.011 & -0.152 & 0.379 & 0.282 & -0.219 & 0.367 & 0.161 & 0.188 & 0.026 & 0.285 \\
\hline $\mathrm{EC}$ & 0.306 & 0.001 & -0.209 & -0.177 & -0.131 & -0.159 & -0.026 & -0.149 & -0.131 & -0.011 & -0.315 & -0.050 & -0.100 & -0.193 \\
\hline TDS & 0.311 & -0.076 & -0.198 & -0.232 & -0.146 & -0.151 & -0.088 & -0.202 & -0.153 & -0.095 & -0.332 & -0.095 & -0.156 & -0.239 \\
\hline Total Alkalinity & -0.201 & 0.487 & -0.083 & 0.425 & 0.462 & 0.164 & 0.084 & -0.112 & \begin{tabular}{|l|}
-0.193 \\
\end{tabular} & -0.104 & -0.298 & -0.347 & -0.278 & -0.106 \\
\hline D0 & -0.039 & -0.025 & -0.160 & 0.004 & 0.101 & -0.157 & -0.273 & 0.279 & 0.246 & 0.155 & -0.029 & 0.039 & 0.153 & 0.165 \\
\hline BOD & 0.142 & 0.000 & 0.279 & 0.086 & -0.034 & -0.108 & -0.126 & 0.143 & \begin{tabular}{|l|}
-0.334 \\
\end{tabular} & 0.180 & -0.246 & -0.125 & -0.246 & 0.218 \\
\hline Ammonia-N & -0.125 & 0.072 & -0.415 & -0.60 & 0.030 & -0.248 & -0.187 & -0.359 & 0.007 & -0.028 & -0.281 & -0.196 & -0.127 & -0.233 \\
\hline Nitrite-N & 0.348 & -0.262 & -0.147 & -0.401 & -0.256 & -0.009 & -0.262 & -0.097 & -0.156 & -0.303 & -0.248 & \begin{tabular}{|l|}
-0.126 \\
\end{tabular} & \begin{tabular}{|l|}
-0.103 \\
\end{tabular} & -0.338 \\
\hline Nitrate-N & -0.229 & -0.089 & -0.078 & -0.006 & 0.095 & -0.094 & -0.242 & 0.143 & -0.334 & -0.148 & -0.161 & -0.282 & -0.245 & -0.084 \\
\hline Total phosphorus & -0.110 & 0.151 & 0.002 & 0.242 & 0.457 & 0.169 & -0.149 & 0.099 & 0.064 & -0.197 & -0.069 & -0.165 & -0.154 & 0.006 \\
\hline Ortho-phosphate & -0.301 & -0.286 & -0.160 & -0.228 & -0.222 & -0.307 & -0.286 & -0.261 & -0.315 & -0.102 & -0.200 & -0.326 & -0.284 & -0.175 \\
\hline Silica & -0.001 & -0.077 & -0.286 & -0.232 & -0.354 & -0.369 & -0.007 & -0.188 & -0.228 & 0.166 & -0.214 & -0.052 & -0.038 & -0.157 \\
\hline Chlorides & -0.031 & 0.432 & -0.049 & 0.345 & 0.208 & 0.010 & 0.222 & 0.283 & 0.127 & 0.358 & -0.010 & 0.118 & 0.207 & 0.233 \\
\hline Total-Hardness & -0.137 & 0.105 & -0.296 & -0.004 & -0.073 & -0.315 & -0.005 & -0.047 & \begin{tabular}{|c|}
-0.198 \\
\end{tabular} & 0.187 & -0.218 & $\mid-0.100$ & -0.069 & -0.073 \\
\hline
\end{tabular}

Egyptian J. of Phycol. Vol. 12, 2011

-40 - 


\section{Discussion}

Climatic conditions particularly water temperature has been reported to strongly affect the community composition, growth and bioactivity of marine algae (Trono and Tolentino, 1992). The limited local and seasonal variation in water temperature of the sites of study is a reflection of the moderate climate prevailing in Egypt. The slight seasonal and local fluctuation in water $\mathrm{pH}$, with an overall slightly alkaline reaction might be due to the buffering activity of the bicarbonate system associated with production of $\mathrm{CO}_{2}$ and the water dissolved oxygen. Reynolds (1976) concluded that, photosynthesis and respiration of aquatic biota has been controlled the $\mathrm{pH}$ value in aquatic system.

The relatively low levels of salinity, chloride, total hardness, electric conductivity; dissolved oxygen along with the relatively high level of BOD at Faied can be attributed to the agricultural effluents discharged at north Faied. Abdel Baky (2001) reported that, increasing the organic matter content of water can lower the dissolved oxygen content. The lowering in salinity, EC, TDS, total hardness and chloride content during winter was consistent with the low temperature, high $\mathrm{pH}$ values and less evaporative loss. Efe $\boldsymbol{e t}$ al. (2005) revealed that the decrease of EC during winter was related to the low temperature and high $\mathrm{pH}$ values. Meanwhile the high TDS, chloride, total hardness, EC and dissolved oxygen contents at Safaga during summer may be due to the high rate of evaporation and the absence of continuous enrichment with fresh and/or brackish water. Moreover, water turbulence arising from wave action would lead to less amount pollutants and increase the dissolved oxygen content in water at Safaga. Salinity and TDS influence growth rate of algae (Polat and Işik, 2002).

The high levels of water alkalinity, nitrite, nitrate, ammonia and BOD encountered at Faied during spring and the low levels of these characteristics at Safaga especially during winter can be related to the agricultural discharges which increase the levels of nutrients in water at north Faied and might point to the low polluted status of water at Safaga. Turkoglu and Koray (2002) concluded that, the agricultural drainage increase level of trophic status in water. Total phosphorus content of water exhibited considerable seasonal and local variation. High phosphorous content during spring and summer may be due to the anthropogenic activity arising from intensive tourism during that time of the year. The strikingly high levels phosphorous at Safaga followed by Faied may be due to the loading of raw phosphate at Safaga and to the sewage, agricultural and industrial waste discharges at north Faied. These findings are in agreement with those of Abdel Baky (2001).

The high water silica at Faied during summer can be related to the low diatom growth, high recycling rate of silicon and intensive industrial discharge. By contrast the low levels of silica at Safaga during autumn can be related to the high diatom growth and the very low water pollution therein. Kebede $\boldsymbol{e t}$ al. 
(1994) reported that vigorous diatom population was inversely related with silica concentration in sea water.

The local and temporal variations in the dominance of $L$. obtusa could be attributable to variation in the eutrophic status of water, temperature and the light regime. Díaz et al., (2002) indicated that the macroalgal growth was controlled by eutrophication levels of intertidal habitat. The favorite growth of L. obtusa during the warm seasons (summer and autumn) particularly at Faied can be related to the relatively high eutrophic status and the favorable temperature of water. Likewise, timing of maximum growth of L. obtusa at Safaga during winter may be related to the relatively higher temperature at that site than the other two sites during winter.

The relatively high contents of carbohydrates, lipids and proteins in $L$. obtusa at Faied compared to those at Safaga may be due to the high eutrophication status of water as a result of agricultural drainage at Faied while the water at Safaga is least polluted. The seasonal pattern of these bio-contents, with a maximum during summer and a minimum during spring is in accordance with the pattern of seasonal dominance exhibited by the alga and may be related to the seasonal fluctuation in temperature (Shanmugam and Palpandi, 2008). The seasonal and regional variation in mineral content of L. obtusa can be related to the seasonal and local variations in mineral content of water as well as water temperature. The mineral content of macroalgae has been found to vary with temperature and the trophic status of water (Krishnaiah et al., 2008). The high phosphorous content of L. obtusa at Safaga and Faied relative to the third site Ras Gharib could be related to the high load of inorganic phosphorous in water due to processing of rock phosphate at Safaga and to the agricultural drainage stations at north Faied. Cd was highest detected in L. obtusa followed by Co, Mn, $\mathrm{Zn}, \mathrm{Cu}$ and Fe. The heavy metal content of L. obtusa exhibited small seasonal and regional variation. The seasonal variation of heavy metal contents of seaweeds were controlled by heavy metal levels in marine water. This may be due to the limited seasonal and long-term variation in heavy metal levels in the marine environment (Villares et al., 2002). The presence of high levels of $\mathrm{Cd}$ in the algal tissues and in sea water refers to the polluted nature of water. Furthermore, variation of the bioaccumulation capacity and bioconsumption of L. obtusa for different heavy metals might control the heavy metal content of the alga. Where, Das et al. (1997) indicated that the heavy metal contents of organism depend on its bioaccumulation capacity and bioconsumption for these heavy metals.

The chloroform extract of L. obtusa was more efficient as antibacterial than as antifungal. The antimicrobial potency of the extract was highest from algae harvested at Safaga during autumn and winter and lowest from algae harvested at Faied during spring and summer. This points to a probable rise in the levels of the active antimicrobial secondary metabolites under stress conditions 
(unfavorable growth season) at the expense of a lowering in the primary metabolites involving proteins, carbohydrates and lipids. The highest antibacterial of the algal extract activity was recorded against $P$. aeruginosae and the lowest against $E$. coli. similar results were obtained by Crasta et al. (1997).

The differential antibacterial activity of the algal extract against different bacterial species which also varied according to the growth season may be due to the structural differences between the bacterial species tested and the seasonal variation in the levels of antimicrobial compounds in the algal extract. This is in agreement with (Padmini Sreenivasa Rao, 1998) who demonstrated differential antibacterial activity of the diethyl ether extracts of Sargassum johnstonii against Proteus vulgaris according to the season of growth. The seasonal environmental fluctuations might be reflected on the pattern of algal growth (growth rates and growth shapes), which in turn lead to different antimicrobial activity of the algal extract (Hellio et al., 2004). The antibacterial activity of L. obtusa was positively correlated with the water $\mathrm{pH}$, alkalinity, phosphorus and chloride contents but negatively correlated with temperature, ammonia and silica. The antifungal activity showed positive correlation with $\mathrm{pH}$ and chloride but negative correlation with alkalinity; nitrite, ammonia and nitrate. Similar results were obtained by Marti et al. (2004).

In conclusion: Growth and chemical composition of L. obtusa varied in response to the seasonal and local variation in water quality at the Red Sea coast of Egypt. Algal growth and content of primary metabolites (proteins, carbohydrates and lipids) was maximum during summer and autumn, in a reverse relationship with the antimicrobial activity of the algal extract which was more powerful as antibacterial than as antifungal. The anthropogenic activities such as intensive tourism and discharge of agricultural drainage into the Red sea altered the local and temporal variation in water characteristics. Further studies are needed to isolate and identify the antimicrobial compounds in L. obtuse extracts for utilization in industrial and pharmaceutical applications.

\section{References}

Abdel Baky, T. E. (2001). Heavy metals concentrations in the cat fish Claries gariepinus from River Nile, El-Salam Canal and Lake Manzala and their impact on cortisol and thyroid hormones, Egypt. J. Aqua. Biol. and fish., 5 (1): 79- 98.

Abou-Aisha, K.M.; Kobbia, I. A.; El-Abyad, M. S.; Shabana, E. F. and Schanz, F. (1995). Impact of phosphorus loading on macro-algal communities in the Red Sea coast of Egypt. Water, Air and Soil Pollution, 83: 285-297.

AOCS (1993). Official methods and recommended practices. The American Oil Chemists Society, Champaign, IL, USA. 
Attaway, D. H. and Zaborsky, O. R. (1993). Marine Biotechnology Vol. 1. Pharmaceutical and Bioactive Natural Products, edited by. David H. Attaway and Oskar R. Zaborsky. Plenum Press, New York,524pp.

Bradford, M. M. (1976). A Rapid and Sensitive Method for The Quantitation of Microgram Quantities of Protein Utilizing The Principle of Protein Dye Binding. Analytical Biochemistry, 72: 248-254.

Calvo, M. A.; Cabanes, F. J. and Abarca, L. (1986). Antifungal activity of some Mediterranean algae. Mycopathologia, 93: 61-63.

Crasta, J.P.; Raviraja, N. S. and Sridhar, K. R. (1997). Antimicrobial activity of some marine algae of southwest coast of India. Indian J. Marine Science, 26:201-205.

Das, P.; Samantaray, S. and Rout, G. R. (1997). Studies on cadmium toxicity in plants: A Review. Environ. Pollut., 98(1):29-36.

Demirel, Z.; Yilmaz-Koz, F. F.; Karabay-Yavasoglu, N. U.; Ozdemir, G. and Sukatar, A. (2011). Antimicrobial and antioxidant activities of solvent extracts and the essential oil composition of Laurencia obtusa and Laurencia obtusa var. pyramidata. Romanian Biotechnology Letters, 16(1): 5927-5936.

Díaz, P.; López Goppa, J.J. and Piriz, M. L. (2002). Symptoms of eutrophication in intertidal macroalgal assemblages of Nuevo Gulf (Patagonia, Argentina). Botanica Marina, 45: 267- 273.

Efe, S. I.; Ogban, F. E.; Horsfall, M. Jr. and Akporhonor, E. E. (2005). Seasonal variations of physico-chemical characteristics in water resources quality in Western Niger Delta Region, Nigeria. J. Appl. Sci. Environ. Mgt., 9(1): 191-195.

Erickson, K. L. (1983). Constituents of Laurencia. In: Marine Natural Products (by Scheuer, P. J. ed.) Vol. 5, pp. 131-257. Academic Press, New York.

Hawk, F. P.; Oser, B. L. and Summerson, W. H. (1947). Practical Physiological Chemistry, $12^{\text {th }}$ ed.Philadelphia and Toronto: Blakiston.

Head, S. M. (1987). Corals and coral reefs of the Rea Sea. In: Red Sea Key Environments Series. Edwards, A. J. \& Head, S.M. (eds). Pp. 128- 151. Pergamon Press, Oxford.

Hellio, C.; Jean-Philippe, M.; Benoît, V.; Graham, B.; Anthony, S. C. and Yves, G. (2004). Seasonal variation of antifouling activities of marine algae from the Brittany coast (France). Mar. Biotechnol.(NY), 6(1): 67-82.

John, M. K. (1970). Colorimetric determination of phosphorus in soil and plant materials with ascorbic acid. Soil Sci., 109(4): 214-220.

Kebede, E.; Mariam, Z. G. and Ahlgren, I. (1994). The Ethiopian Rift Valley Lakes: chemical characteristics of a salinity-alkalinity series. Hydrobiol., 288: 1- 12.

Krishnaiah, D.; Sarbatly, R.; Prasad, D. M. R. and Bono, A. (2008). Mineral Content of Some Seaweeds from Sabah's China Sea. Asian Journal of Scientific Research, 1(2): 166-170.

Egyptian J. of Phycol. Vol. 12, 2011 
Kuwana, K.; Matsuka, S.; Kono, S.; Ninomiya, M.; Onishi, J. and Saga, N. (1998). Growth and the content of laurinterol and debromolaurinterol in Laurencia okamurae (Ceramiales, Rhodophyta). J. Appl. Phycol., 10(1): 9-14.

Lima-Fihlo, J. V. M.; Carvahlo, A. F. F. U.; Freitas, S. M. and Melo, V. M. M. (2002). Antibacterial activity of extracts of six macroalgae from the Northeastern Brazilian Coast. Braz. J. Microbiol., 33: 311-313.

Marti, R.; Uriz, M. and Turon, X. (2004). Seasonal and spatial variation of species toxicity in Mediterranean seaweed communities: correlation to biotic and abiotic factors. Mar. Ecol. Prog. Ser., 282: 73-85.

Martin, J. D. and Darias, J. (1978). Algal Sesquiterpenoids. In: Marine Natural Products (Scheuer, P. J. ed.), Vol. 1, pp. 125-173. Academic Press, New York.

Martin, J. D. ; Caballelo, P.; Fernandez, J. J. ; Norte, M. ; Perez, R. and Rodriguez, M. L. (1989). Metabolites from Laurencia obtuse. Phytochemistry, 28(12):3365-3367.

Moore, P. J. and Chapman, S. B. (eds) (1986). Methods in Plant Ecology. Second Edition, Blackwell Scientific Publication, Oxford. 536pp.

Padmini Sreenivasa Rao, P. (1998). Biological investigations of Indian phaeophyceae: 17. Seasonal variation of antibacterial activity of total sterols obtained from frozen samples of Sargassum johnstonii Setchell et Gardner. Seaweed Research and Utilization, $20(1$ and 2): 91-95.

Polat, S. and Işik, O. (2002). Phytoplankton distribution, diversity and nutrients at the northeastern Mediterranean coast of Turkey (Karataş- Adana). Turk. J. Bot., 26: 77- 86.

Reynolds, C. S. (1976). Succession and vertical distribution of phytoplankton in response to thermal stratification in a lowland mere, with special reference to nutrients availability. J. Ecol., 64: 529-551.

Schortemeyer, M.; Stamp, P. and Feil, B. (1997). Ammonium Tolerance and Carbohydrate Status in Maize Cultivars. Annual of Botany, 79: 25-30.

Shanmugam, A. and Palpandi, C. (2008). Biochemical Composition and Fatty Acid Profile of the Green Alga Ulva reticulata. Asian J. Biochem., 3: 2631.

Strikland, J. D. H. and Parsons, T. R. (1972). A Practical Handbook of Seawater Analysis. $2^{\text {nd }}$ ed. Bull. Fish. Res. Bd. Can., Ottawa. 167: 310 pp.

Trono, G. C. Jr. and Tolentino, G. L. (1992). The reproductive phenology of Sargassum Sp. (Fucales, Phaeophyta) in Bolinao, Pangasinan. In: Calumpong. HP, Meñez EG, editors. Proceeding of the 2nd Rp-USA Phycology Symposium/ Workshop. Los Baños, Laguna, Philippines: Philippine Council for Aquatic and Marine Research and Development. p. 181-193. 
Turkoglu, M. and Koray, T. (2002). Phytoplankton species' Succession and nutrients in the Southern Black sea (Bay of Sinop). Turk. J. Bot., 26: 235252.

Villares, R. ; Puente, X. and Carballeira, A. (2002). Seasonal variation and background levels of heavy metals in two green seaweeds. Environ. Pollut., 119(1): 79-90.

$$
\begin{aligned}
& \text { المحتوى البيوكيميائى والنشاط البيولوجى لطحلب اللورانشيا اوبتوزا وعلاقتها }
\end{aligned}
$$

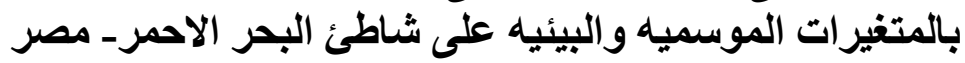

$$
\begin{aligned}
& \text { محمد على ابر اهيم دياب } \\
& \text { قسم النبات ـ كلية العلوم بدمباط ـ جامعة المنصورة- دمباط الجديلة }
\end{aligned}
$$

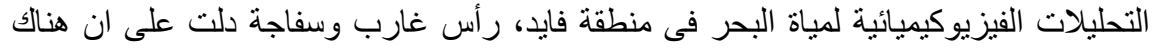

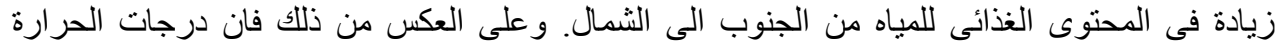

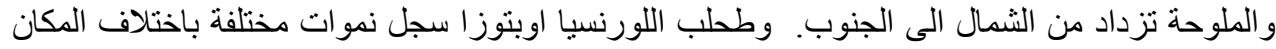

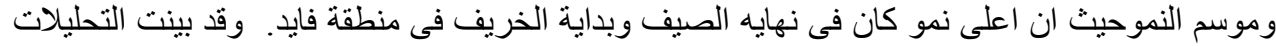

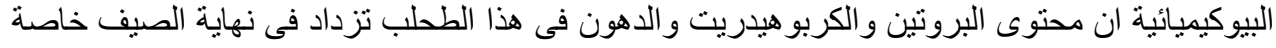

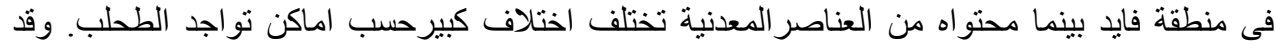

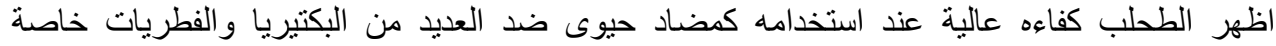
البوسيدومونس و الفيوزريم خلال موسمى الخريف و الثناء. 